\title{
An Investigation into the Causes, Effects and Solutions to Cultism in Tertiary Institutions in Southwest, Nigeria
}

\author{
Abdu-Raheem Bilqees Olayinka Ph. D \\ Department of Social Science Education \\ Faculty of Education \\ Ekiti State University \\ Ado-Ekiti, Nigeria
}

\begin{abstract}
This study investigated the causes, effects and solutions to cultism in tertiary institutions in Southwest, Nigeria. The study adopted descriptive research design of the survey type. The population consisted of all lecturers in universities in Southwest Nigeria. The sample conprised of 500 lecturers selected from 10 universities including Federal, state and private owned using multistage sampling procedure. Simple random sampling technique was adopted to select two federal, three states and five private universities. Simple random sampling was also used to select fifty lecturers from each university sampled to make a total of 500 lecturers selected from ten universities. The instrument used for the study was a questionnaire titled Causes, Effects and Solutions to Cultism in Tertiary Institutions Questionnaire(CESCTIQ). The validity of the instrument was established through face and content validity while the reliability of the instrument was determined using Cronbach Alpha and a reliability co-efficient of 0.77 was obtained. The data collected were analyzed using mean and percentage statistical tools. It was found in the study that the major causes of cultism are collapse of family, inadequate care of children, peer influence, ignorance, indiscipline and boosting of ego of cult members. It was also confirmed in the study that effects of cultism are poor academic performance, suspension and expulsion of cult members, and loss of innocent lives of students and staff in the universities. It was therefore recommendedthat parents should avoid divorce to give adequate care to their children. Children should obey theparents and keep away from bad groups. Government should improve the quality of education.
\end{abstract}

Keywords: Cultism, Tertiary Institution, Southwest, Academic excellence, hazard,unscrupulous groups.

\section{Introduction}

Tertiary institutions in Nigeria, particularly the Universities, are set up to train the nation's youth to become useful, responsible, patriotic and reliable future leaders with high moral and professional standards. Regrettably, large numbers of students admitted to these institutions turned out to become wayward, irresponsible, unpatriotic and unreliable citizens through their involvement in cultism.Jekayinfaand Kolawole(2010) posited that the singular purpose of education is to produce a useful citizen.Abdu-Raheem (2015) noted that education is a processwhereby a person develops attitudes and abilities that are considered to have values and relevance in the society. Abdu-Raheem (2017) also saw education received in tertiary institutions of learning as an ornament or a golden key to the acquisition of knowledge and development of desirable and purposeful skills to enable one live a comfortable and achievement-filled life.Ekundayo (2019) added that higher level education is considered to be an instrument of social change and economic development.

While Nigeria as a country commits to providing education for all her citizens, especially the youth (National Policy on Education, 2013), manystudents in tertiary institutions of learning engage inunrulybehaviours such as cultism, raping, killing and maiming of colleagues and staff,armed robbery, stealing, internet fraud, kidnapping and political thuggery. Ajayi and Ekundayo (2010) posited that cultism is an anti-social behaviour that is in an alarming dimension in Nigerian tertiary institutions. Anjorin and Popoola(2018) asserted that tertiary institutions used to be in charge of social atmosphere and academic excellence until the situation turned around in the last two decades when cultism reared its dreadful head on campuses. Olofintoye, Alade and Olusegun (2018) posited that cultism is noted in students' unionism, demonstrations or protests, disruption of lectures, sexual harassment, examination misconduct, stealing, vandalism and provocation of students and staff members. 
The acceleratingspeed at which cultism is growing in tertiary institutions in Nigeria is worrisome to education stakeholders and the nation at large.Cult groups wreck a lot of havoc on Nigeria educational campuses whenever they strike against one another by maiming and killing with acids, charms, machetes, knives, guns and other dangerous weapons.Dauda (2006) observed that there are incidences of cult activities with oath taking, blood sucking ceremonies, burglary and raping involving sons and daughters of highly placed members of the society under the influence of drugs on campuses. Adegbite (2007) posited that cultism among students has opened a new and very dangerous dimension of things in higher institutions of learning.Ajayi, Ekundayo and Osalusi (2010) observed that there is hardly any existing single higher institution of learning that has not experienced the menace of cultism. They stressed that aggressiveness of cult members, cult-related violent clashes and activities on most tertiary institution campuses have caused sudden death of lecturers and students. Udoh and Ikezu (2015) attested that cultism has cast gloom over the educational sector. They noted that youths are future leaders but wonder what the future holds for the youth of Nigeria when reasonable numbers of them are secret cult members.

The situation in tertiary institutions is so bad and fearful that lecturers are threatened to award unmerited scores to cultiststhat failed to attend classes (Opaluwah 2000). Secret cult according to Akani (2009) conveys fear, intimidation and insecurity to ordinary people. He explained that cult activities have turned higher educational institutions into breeding grounds for armed robbers, arsonists, rapists, political thugs and perpetrators of all forms of criminal activities on earth, hitherto known to Nigerians. Ogunya (2009) also agreed that secret cult is an association that uses signs rites or symbols and their activities are held mainly in the night, in secret and semidark opaque places. Odudele (2014) maintained that cultism in tertiary institutions in Nigeria shows the degree of moral decadence to which the society has degenerated.Ekundayo and Ajayi (2017) noted that cult activities have gone on an increase since the revitalization of democracy in Nigeria.

In spite of the fact that cultism is a residence of wickedness, where all protocol of immorality and social vices are located, some students still join the various cult groups for many reasons. Some of the factors leading students to be members are poor parental care, boosting of ego, peer group influence, ignorance, inferiority complex, parents' membership of secret cult and indiscipline. According to Ogidefa (2008), there are allegations that some ViceChancellors were sponsoring cult activities in their Universities to silence the voices of antagonists. This is an unfortunate level of decadence reached by some citadels of learning.Ezinwo (2015)asserted that secret cults on campuses are an extension of what operates in the larger society where important personalities such as exgovernors, former ministers, top military officials, business men and lecturers are members of such groups.

Again, Rotimi (2005) stated that students are attracted to cultism because the social environmentin Nigeria Universities, characterised byabsence of intellectual quizzes, debates and traditional academic culture, gives room for such to flourish.. Rotimi (2005) stressed further that some students join secret cult because of "drowsy egos" that need to be boosted while others become members purposely to have a sense of belonging, comfort, love, connection, financial assistance, self- protection and self-direction. Ekundayo (2019) lamented that the most disgusting problem facing tertiary institutions today is how to handle the hazard and ferociousness of secret cult members. He stressed further that unconcealed students' violent reaction to national and international problems has been one of the major miseries to effective university management in Nigeria.

In addition,Olugbenga-Bello, Adebimpe and Abodunrin (2009) confirmed that parents are responsible for the degree of degradation of moral values in the society due to their failure to give moral and spiritual values to the children from home.Alonge (2018) posited that parents of today are more committed to their jobs and income than caring for the children. He noted that care for children is now left in the hands of house-helps and teachers at schools. This type of upbringing is also common with children from broken homes and those reared by foster parents.This lack of good parental care resultsin psychological trauma and behavioural disorderamong such children.

Odudele (2014) noted that charity begins at home. He posited that children are best nurtured, molded and tutored by both parents to enhance good upbringing. Parents serve the first tutors to provide children the desired moral, religious, social and cultural education so as not to be influenced by unscrupulous groups when they become youth. Alonge (2018) also observed that inadequate care by parents and collapse of family institutions in recent time have greatly affected moral values among undergraduates. 


\section{Statement of the Problem}

While education is seen as the best legacy any nation could offer her youth to become responsible citizens, Nigeria youths in tertiary institutions appear to be proving otherwise. This is evident in their involvement in criminal acts, such as cultism, rape, stealing, robbery, advanced internet fraud, drug abuse, indecent dressing, examination malpractices, vandalism, killing and maiming of innocent students and lecturers. In this study, the focus is especially on cultism, which is a menace that has claimed many lives of innocent citizens particularly students, lecturers and principal officers in higher institutions(Ekundayo and Ajayi, 2017). This study posits that cultism, if left unchecked, willnot only ruin and rubish the educational fabric of the country, but plunge the nation in widespread insecurity and chaos.In this light, this study investigated the causes, effects and possible solutions to the menace of secret cult in tertiary institutions in Nigeria.

\section{Research Questions}

The following research questions were raised for the study:

1.What are the causes of cultism in tertiary institutions in Southwest, Nigeria?

2.What are the effects of cultism on tertiaryinstitutions in Southwest, Nigeria?

3.What are the solutions to cultism in tertiary institutions in Southwest, Nigeria?

\section{Methodology}

A descriptive research design of the survey type was adopted for the study. The population comprised all university lecturers in Southwest, Nigeria. The sample consisted of 500 lecturers randomly selected from ten Universities across Southwest, Nigeria. Multistage sampling procedure was used to select the sample. Simple random sampling was used to select two out of seven Federal Universities, three out of eleven state universities and five out of 37 private universities in Southwest, Nigeria. Simple random sampling was used to select 50 lecturers across the faculties from each university to make a total of 500 lecturers. The distribution and collection of the instrument was done through the research assistants. The instrument used was a questionnaire designed by the researcher titled Causes, Effects and Solutions to Cultism in Tertiary Institutions Questionnaire' (CESCTIQ). The validity of the instrument was determined through face and content validity procedures by experts in Social Studies, Educational Management and Test, Measurement and Evaluation. The reliability of the instrument was ascertained using Cronbach Alpha and the reliability coefficient of 0.77 was obtained. Three research questions were raised for the study. The data collected were analysed using Mean and Percentage statistical tools.

\section{Results and Discussion}

Research Question 1: What are the causes of cultism in tertiary institutions in Southwest, Nigeria?

Table 1: Causes of Cultism in Tertiary Institutions in Southwest, Nigeria.

\begin{tabular}{|c|c|c|c|c|c|c|}
\hline $\mathbf{S} / \mathbf{N}$ & ITEMS & $\mathbf{S A}$ & $\mathbf{A}$ & $\mathbf{D}$ & SD & MEAN \\
\hline 1 & Male students involve more in secret cult activities & $\begin{array}{l}195 \\
(48.8 \%)\end{array}$ & $\begin{array}{l}117 \\
(29.3 \%)\end{array}$ & $\begin{array}{l}88 \\
(22.0 \%)\end{array}$ & & 3.27 \\
\hline 2 & Female students involve more in secret cult activities. & & $\begin{array}{l}89 \\
(22.3 \%)\end{array}$ & $\begin{array}{l}292 \\
(73.0 \%)\end{array}$ & $\begin{array}{l}19 \\
(4.8 \%)\end{array}$ & 2.18 \\
\hline 3 & Students from rural areas involve more in cultism & $\begin{array}{l}19 \\
(4.8 \%)\end{array}$ & $\begin{array}{l}45 \\
(11.3 \%)\end{array}$ & $\begin{array}{l}292 \\
(73.0)\end{array}$ & $\begin{array}{l}44 \\
(11.0)\end{array}$ & 2.10 \\
\hline 4 & $\begin{array}{l}\text { Peer group influence is one of the reasons why students } \\
\text { join cultism }\end{array}$ & $\begin{array}{l}250 \\
(62.5 \%)\end{array}$ & $\begin{array}{l}63 \\
(15.8 \%)\end{array}$ & $\begin{array}{l}87 \\
(21.8 \%)\end{array}$ & & 3.41 \\
\hline 5 & Students from urban areas involve more in cultism & $\begin{array}{l}226 \\
(56.5 \%)\end{array}$ & $\begin{array}{l}87 \\
(21.8 \%)\end{array}$ & $\begin{array}{l}87 \\
(21.8 \%)\end{array}$ & & 3.35 \\
\hline 6 & $\begin{array}{l}\text { Boosting of ego is one of the reasons for joining } \\
\text { cultism }\end{array}$ & $\begin{array}{l}153 \\
(38.3 \%)\end{array}$ & $\begin{array}{l}204 \\
(51.0 \%)\end{array}$ & $\begin{array}{l}43 \\
(10.8 \%)\end{array}$ & & 3.27 \\
\hline 7 & $\begin{array}{l}\text { Ignorance is one of the reasons why students join } \\
\text { cultism }\end{array}$ & $\begin{array}{l}134 \\
(33.5 \%)\end{array}$ & $\begin{array}{l}193 \\
(48.3 \%)\end{array}$ & $\begin{array}{l}73 \\
(18.3 \%)\end{array}$ & & 3.15 \\
\hline 8 & $\begin{array}{l}\text { Indiscipline is one of the reasons why students join } \\
\text { cultism }\end{array}$ & $\begin{array}{l}178 \\
(44.5 \%)\end{array}$ & $\begin{array}{l}179 \\
(44.8 \%)\end{array}$ & $\begin{array}{l}43 \\
(10.8 \%)\end{array}$ & & 3.34 \\
\hline 9 & $\begin{array}{l}\text { Inferiority complexity is one of the reasons why } \\
\text { students join cultism }\end{array}$ & $\begin{array}{l}89 \\
(22.3 \%)\end{array}$ & $\begin{array}{l}161 \\
(40.3 \%)\end{array}$ & $\begin{array}{l}131 \\
(32.8 \%)\end{array}$ & $\begin{array}{l}19 \\
(4.8 \%)\end{array}$ & 2.80 \\
\hline
\end{tabular}




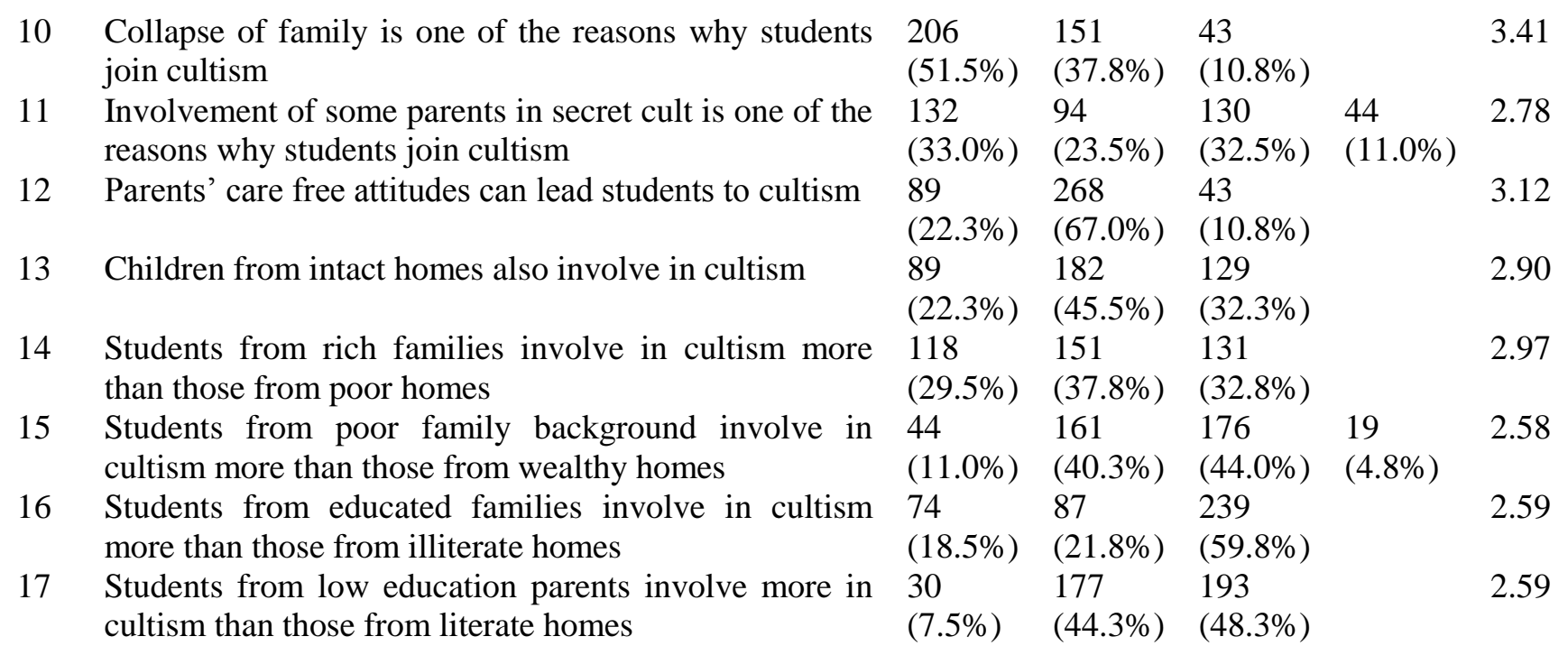

Research Question 2: What are the effects of cultism on tertiary institutions in Southwest, Nigeria?

Table 2: Effects of Cultism on Tertiary Institutions in Southwest, Nigeria

\begin{tabular}{|c|c|c|c|c|c|c|}
\hline $\mathbf{S} / \mathbf{N}$ & ITEMS & SA & $\mathbf{A}$ & D & SD & MEAN \\
\hline 1 & $\begin{array}{l}\text { One of the effects of cultism is low academic } \\
\text { performance among the cult members }\end{array}$ & $\begin{array}{l}75 \\
(18.8 \%)\end{array}$ & $\begin{array}{l}107 \\
(26.8 \%)\end{array}$ & $\begin{array}{l}174 \\
(43.5 \%)\end{array}$ & $\begin{array}{l}44 \\
(11.0 \%)\end{array}$ & 2.53 \\
\hline 2 & $\begin{array}{l}\text { Suspension and expulsion of cult members have effects } \\
\text { on the group. }\end{array}$ & $\begin{array}{l}45 \\
(11.3 \%)\end{array}$ & $\begin{array}{l}224 \\
(56.0 \%)\end{array}$ & $\begin{array}{l}87 \\
(21.8 \%)\end{array}$ & $\begin{array}{l}44 \\
(11.0 \%)\end{array}$ & 2.67 \\
\hline 3 & $\begin{array}{l}\text { Loss of innocent lives and property are effects of } \\
\text { cultism }\end{array}$ & $\begin{array}{l}108 \\
(27.0 \%)\end{array}$ & $\begin{array}{l}162 \\
(40.5 \%)\end{array}$ & $\begin{array}{l}86 \\
(21.5 \%)\end{array}$ & $\begin{array}{l}44 \\
(11.0 \%)\end{array}$ & 2.83 \\
\hline 4 & Insecurity of lives and property are effects of cultism & $\begin{array}{l}108 \\
(27.0 \%)\end{array}$ & $\begin{array}{l}205 \\
(51.3 \%)\end{array}$ & $\begin{array}{l}43 \\
(10.8 \%)\end{array}$ & $\begin{array}{l}44 \\
(11.0 \%)\end{array}$ & 2.94 \\
\hline 5 & $\begin{array}{l}\text { Untimely death of secret cult members is one of the } \\
\text { effects of cultism }\end{array}$ & $\begin{array}{l}153 \\
(38.3 \%)\end{array}$ & $\begin{array}{l}160 \\
(40.0 \%)\end{array}$ & $\begin{array}{l}43 \\
(10.8 \%)\end{array}$ & $\begin{array}{l}44 \\
(11.0 \%)\end{array}$ & 3.06 \\
\hline 6 & $\begin{array}{l}\text { Disgrace to parents and families of cult members is one } \\
\text { of the effects of cultism }\end{array}$ & $\begin{array}{l}89 \\
(22.3 \%)\end{array}$ & $\begin{array}{l}224 \\
(56.0 \%)\end{array}$ & $\begin{array}{l}43 \\
(10.8 \%)\end{array}$ & $\begin{array}{l}44 \\
(11.0 \%)\end{array}$ & 2.90 \\
\hline
\end{tabular}

Research Question 3: What are the solutions to cultism in tertiary institutions in Southwest, Nigeria?

Table 3: Solutions to Cultism in Tertiary Institutions in Southwest, Nigeria

\begin{tabular}{|c|c|c|c|c|c|c|}
\hline $\mathbf{S} / \mathbf{N}$ & ITEMS & SA & $\mathbf{A}$ & D & SD & MEAN \\
\hline 1 & $\begin{array}{l}\text { Improvement on quality education is one of the } \\
\text { solutions to cultism }\end{array}$ & $\begin{array}{l}164 \\
(41.0 \%)\end{array}$ & $\begin{array}{l}174 \\
(43.5 \%)\end{array}$ & $\begin{array}{l}62 \\
(15.5 \%)\end{array}$ & & 3.26 \\
\hline 2 & $\begin{array}{l}\text { Establishment of functional counseling services in } \\
\text { tertiary institutions is one of the solutions to cultism }\end{array}$ & $\begin{array}{l}197 \\
(49.3 \%)\end{array}$ & $\begin{array}{l}117 \\
(29.2 \%)\end{array}$ & $\begin{array}{l}86 \\
(21.3 \%)\end{array}$ & & 3.28 \\
\hline 3 & Religious admonition is one of the solutions to cultism & $\begin{array}{l}164 \\
(41.0 \%)\end{array}$ & $\begin{array}{l}193 \\
(48.3 \%)\end{array}$ & $\begin{array}{l}43 \\
(10.8 \%)\end{array}$ & & 3.30 \\
\hline 4 & $\begin{array}{l}\text { Public enlightenment programmes are among the } \\
\text { solutions to cultism }\end{array}$ & $\begin{array}{l}164 \\
(41.0 \%)\end{array}$ & $\begin{array}{l}149 \\
(37.3 \%)\end{array}$ & $\begin{array}{l}43 \\
(10.8 \%)\end{array}$ & $\begin{array}{l}44 \\
(11.0 \%)\end{array}$ & 3.08 \\
\hline 5 & Family cohesion is one of the solutions to cultism. & $\begin{array}{l}208 \\
(52.0 \%)\end{array}$ & $\begin{array}{l}105 \\
(26.3 \%)\end{array}$ & $\begin{array}{l}43 \\
(10.8 \%)\end{array}$ & $\begin{array}{l}44 \\
(11.0 \%)\end{array}$ & 3.19 \\
\hline 6 & $\begin{array}{l}\text { Adequate care of parents for the children is one of the } \\
\text { solutions to cultism }\end{array}$ & $\begin{array}{l}183 \\
(45.8 \%)\end{array}$ & $\begin{array}{l}174 \\
(43.5 \%)\end{array}$ & $\begin{array}{l}43 \\
(10.8 \%)\end{array}$ & & 3.35 \\
\hline
\end{tabular}

\section{Conclusion}

It was concluded in the study that some of the major causes of cultism are collapse of family, carefree attitudes of parents, boosting of ego of cult members, peer influence, ignorance and indiscipline. It was also noted that the most pronounced effects of cultism are poor academic performance, suspension and expulsion of cult members, and loss of innocent lives and property in the universities. The study also found that family cohesion and adequate 
care of parents for children, improvement on quality education, establishment of functional counselling services and religious admonition are the best solutions to eradication of cultism among students in tertiary institutions in Southwest, Nigeria.

\section{Recommendations}

1. Students should obey their parents by imbibing moral, spiritual and societal values giving to them from home.

2. Students should keep off from keeping of bad friends that can initiate them to cultism which could eventually lead to shame, expulsion from schools, untimely death, and damage of family identity.

3. Couples should maintain peace among themselves so as to avoid divorce and jointly take proper care of their children. This is to enable them guide against their children joining bad groups which can destroy the image of the family in the future.

4. Parents should endeavour to give their children sound moral and spiritual education and also keep on monitoring them from birth till they graduate from higher institutions. This could assist the children to keep off from dangerous groups like secret cult in tertiary institutions.

5. Government should avoid giving admission to under-aged students from secondary schools to tertiary institutions. This could go a long way to reduce the number of students that fall to the trap of secret cults in higher institutions.

6. Government should improve the quality of education across the country in terms of provision of standard libraries, laboratories, classrooms, halls, water, electricity, resource centres, and continual institutional databases to provide enabling environment for learning and discourage idleness which can lead to secret cult activities.

\section{References}

Abdu-Raheem, B.O. (2015). Parents' socio-economic status as predictor of secondary school students' academic performance in Ekiti state, Nigeria, Journal of Education and Practice 6 (1): 123-128

Abdu-Raheem, B.O. (2017). The menace of secret cults in Nigeria tertiary institutions: Issues and the wayout. (Eds) In J.A. Adegun, Babalola, J.B. and Ajayi, I.A. Dynamics of Education. 1 (2): 265-283.

Adegbite, J.G.O. (2007). The education reform agenda: Challenges for tertiaryeducation administration in Nigeria, being a paper presented at the annual seminar of the conference of Registrars of Colleges of Education, Ikere-Ekiti, Ekiti state, June 12-13.

Ajayi, I. A. \&Ekundayo, H.T. (2010) Contemporary issues in educational management, Ikeja, Lagos, Bolabay Publications.

Ajayi, I. A., Ekundayo, H.T. \&Osalusi. F.M. (2010).Menace of cultism in Nigeria tertiary institutions: The way out. Anthropology. 12 (3): 155-160

Akani, C. (2009). Secret Cult in Nigeria tertiary institutions: their origin nature and activities in J. Ogunye, S. Jegede and E. Akinsola (Eds) Citadels of Violence, Lagos CDHR 49 - 79.

Alonge, R.A. (2018). The impact of family structure and social values on university undergraduates' sexual behaviour in the twenty-first century.Social Science Education Journal 2(1):81-85.

Anjorin, B.F. \&Popoola, E.O. (2018). Student' perception on the influence of cultism on students' academic performance in Ekiti state university. Social Science Education Journal 2(2):115-119

Dauda, G. (2006). Curbing the menace of cultism in our university campuses http://www.krepublisher.com

Ekundayo, H.T. \&Ajayi. I.A. (2017). Towards developing human capital for managing security challenges in Nigeria., (Eds) In J.A. Adegun, Babalola, J.B. and Ajayi, I.A. Dynamics of Education. 1 (2): 15-27.

Ekundayo, H.T. (2019).Educational Management: Theory and Practice. Ado-Ekiti, Ekiti State University Printing Press.

Ezinwo, I.O. (2015). Our society and secret cults the Nigerian observer. May 28.

Federal Republic of Nigeria (2013), National Policy on Education, Lgos, NERDC.

Jekayinfa A.A.\&Kolawole, D.O. (2010). Conceptual background to the history of education in Nigeria,(Eds) In J.O.O. Abiriand Jekayinfa, A.A.Perspective on the History of Education in Nigeria. Ilorin, Kwara state, Bamitex Printing and Publication Enterprise.

Odudele, R. (2014). The efficacy of moral/religious counseling in checking cultism in Nigerian institutions of higher learning. International Journal of Humanities and Social Science, 4(13): 1-4. 
Olofintoye, T.T., Alade, F.A. and Olusegun, G.F. (2018). Psychosocial strategies for eradicating cultism in tertiary institutions in Nigeria. Educational Perspectives, 1:85-92. A Book of Reading in honour of Professor DonatusOjiakudiniroOwuamanam.

Opaluwah, A.B. (2000). Cultism and Nigerian campuses: The way out. http:www.ganji.com

Olugbenga-Bello, I .A, Adebimpe, W. O. \&Aboderin, O. L. (2009). Sexual risk behaviour among in-school adolescents in public secondary schools in Southwestern, Nigeria. International Journal of Health Research. 2 (3):243-251.

Ogidefa, I. (2008). Cultism in educational institutions in Nigeria: Causes, possible solutions and counseling implications www.derifider.com. Retrieved on 08/01/2017.

Ogunya, J. (2009). Campus violence, cultism and Nigerian Campus. Perspective from Art and History. Lagos SOF and Co.

Rotimi, A. (2005). Violence in the citadel: The menace of secret cults in the Nigerian universities. http://wwwnjas.helsinkfi

Udoh, V.C. \&Ikezu, U.J.M. (2014).Causes, effects and strategies for eradicating cultism among students in tertiary institutions in Nigeria: A case study of NnamdiAzikwe University, Akwa, Anambara state, Nigeria. Journal of Research in Humanities and Social Science. 2 (7):12-20 